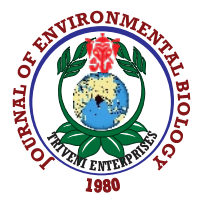

\title{
Examination of Selcuk University Alaaddin Keykubat Campus in the context of ecological landscape design
}

\section{B.O. Kurtaslan}

Selcuk University Agriculture Faculty, Department of Landscape Architecture, Alaaddin Keykubat Campus, Konya, 42075, Turkey

*Corresponding Author Email : bkurtaslan@gmail.com

\begin{abstract}
Aim : The aim of the study was to evaluate the Selcuk University Campus (Konya-Turkey) in terms of ecological design. With this aim, it will be evaluated whether natural environment in the most harmonious and most productive way for the users of the campus.

Methodology: In the research, Selcuk University Alaaddin Keykubat Campus was examined in terms of ecological landscape design. In this context, water-efficient landscaping, design with topography, energy efficient landscape design (energy-efficient landscaping, transportation system etc.), sustainable farming practices, permaculture, the existence of green roof and green wall applications, supporting biodiversity, selection of hard landscaping materials, presence of alternative green areas (green roof, green walls, etc.), and presence of recycling applications were questioned.

Results: Although an ecological appropriate designs were made on Selcuk University Campus. There was not a design approach related to holistic plan. In campus, there were some issues that must be developed in terms of ecological landscape design and planning on some topics such as; energy conservation, waste management, sustainable landscape materials, water management, wildlife/habitat conservation, pest management, landscape maintenace and trasportation and parking. Increase in compost use and diversifying
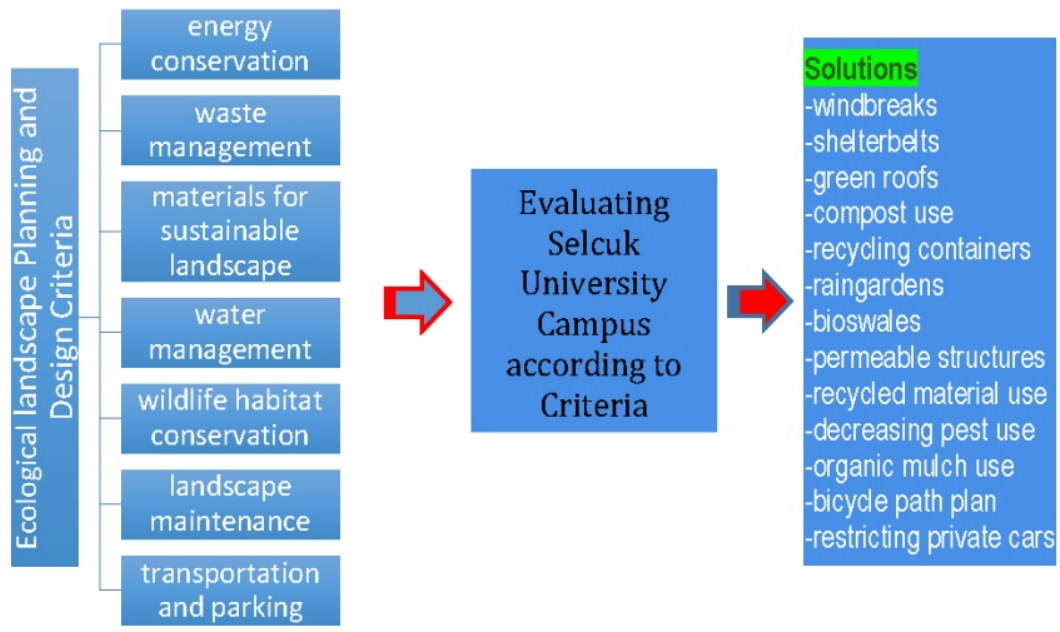
compost materials, creating permeable surfaces rather than materials such as asphalt, concrete etc., that doest not allow rain water to get through, by this way canalizing rain water directly into the soil and reducing surface runoff are few solutions for ecological landscape design and planning.

Interpretation: Achieving campus sustainability and sustainable landscape design more effectively is not possible without the cooperation and involvement of all stakeholders such as students, faculty and staff, university management, funding agencies, and community.
\end{abstract}

Key words: Ecological landscape, Energy conservation, Natural environment, Selcuk University

How to cite : Kurtaslan, B.O.: Examination of Selcuk University Alaaddin Keykubat Campus in the context of ecological landscape design. J. Environ. Biol., 41, 463-474 (2020). 


\section{Introduction}

Human beings exhibiting insensitive attitudes towards nature from an ecological point of view, have come to a stage of limiting their own lives and living spaces. Environmental problems caused by this situation have led to the idea of living in compatable with nature instead of dominating nature (Aklanoğlu, 2009). Throughout 19 th and $20^{\text {th }}$ century, humans had shown no sensitivity towords natural resources. However, in the last quarter of $20^{\text {th }}$ century, issues such as protection of natural environment and resources and curbing pollution was the agenda of governments (Url 1) (Url 2). In 1960s, understanding the limits of urban growth and gradual decline in natural resources changed the outlook on the environment. In 1970s, the energy crisis in the west had a positive impact on planning and design. This situation, brought the effforts for less fossil fuel use, spreading the city and limiting suburban development, transformation efforts for re-use of existing natural resources and necessitated developing more responsible and sensitive methods to the environment on planning an design practices (Kılıç, 2002;Özsoy, 2014; Bogunovich, 2008).

Evidently, the changing views on space planning and design have been associated with ecology in this process. For this reason, ecological design is a solution to the problems in the world at the upper scale and for sustainable cities in the lower scale (Aklanoğlu, 2009).

Ecology is the "study of organisms that interact with each other and with their physical and chemical environment" (Karr, 2002). According to Lawrence (2003), as the common expression of many of the definitions developed since $19^{\text {th }}$ century, ecology is the interaction of all organisms with each other and their environment (Deniz et al., 2006) (Url 1). Ecology works on landscapes, wetlands and streams / corridors with natural processes such as water, biodiversity, rare species and wildlife (Forman, 2001). Landscape ecology is a sub-branch of ecology that focus on landscapes. It involves human influences on the landscape, interaction of change and function of landscape; because these factors mold the spatial unit. Landscape ecology considers natural, physical and biological issues; it also pays attention to cultural, historical and socio-economic issues (Hersperger, 1994).

The ecological approach in design is a generally accepted approach today and more and more technologies and innovative solutions for resource management are applied. Ecological technologies have been created for the food sector, waste conversion industries, architecture and landscape design and to the field of environmental protection and restoration. Ecological technologies have been generated in the waste recycling industry, food sector, architectural and landscape design and environmental protection and restoration (Todd et al., 2003).
The basis of ecological approach is based on the ecological planning. The necessity of integration of planning with design, developments and changes that brought up the concepts of quality of life and sustainability has been the starting point of ecological design. Ecological design of a living environment can be maintained without harming the natural balance despite the nature of natural environment. Ecological design ensures that human-made environment or design systems integrate well with the natural environment in the best possible way (Yeang, 2006).

When all or part of the cities are constructed, different disciplines such as architects, landscape architects, engineers and planners play a role in ecological design as a part of sustainable urban approach (Bogunovich, 2008; Yeang, 2006).

According to Nassauer et al. (2009), ecological design is a design which integrates with natural processes and effectively adapts to the negative effects of the environment by integrating with living processes. It is environmentally sensitive design that considers its effect on people and the environment. Ecological design is a design approach which is an inseperable part of sustainable approach while designing buildings, interiors and landscapes. Green design aims to create healthier environments for people and all habitats. It is committed to conserve energy and water, generate less pollution, manage waste, and use materials with lowest environmental impacts.

Ecological approach in landscape design and management aims at establishing a sustainable system compatible with the environment with minimum natural resource consumption and minimum waste, by examining all structural components of the system and their interaction with each other (Birkeland, 2002). With this objective, some aspects to be considered for the ecological design of a landscape are open space system, right plant selection, hydrological system, active transportation system, recycling, energy and biodiversity.

University campus, which will be examined in terms of ecological landscape design in this study, are open spaces that have the potential to make significant contributions to urban ecology when they are well planned, designed and managed. Campus that have close spatial relations with the city are common areas of use that should be open for citizens as well as research and education activities. University campus are places of the green design principles.

Campus established in the close vicinity of the city in general, are the institutions that make significant contributions to the city and the university in terms of cultural, sporting and recreational activities, and housing and health services. with regard to ecosystem approach, campus are the ecosystem involving heterogeneous, dynamic and human-nature 
relationships (Alshuwaikhat and Abubakar, 2008). In this respect, campus of universities are an important component of urban ecosystems. In addition to the social and economic benefits they offer to the city, the campus, which are located on wider areas compared to other institutional structures, make significant contributions to the ecology of the city with their open and green spaces.

"Each university campus has its own ecological system based on its ecosystem relationship and climate. Variations in climate, sun-shadow patterns, soil, topography and plant selection are determinig issues that influence the size, appearance, and quality of the natural environment of the campus. The primary objective of campus landscape planning is to make decisions about the use of resources. Campus landscape plans offer land uses and connections between buildings, open spaces, parking and transit, recreational areas, and infrastructure".

According to (ULSF, 1999) as a recent publication of the Association of University Leaders for a Sustainable Future clearly indicates, there are many ways in which universities can be involved in sustainable development, e.g. management, planning, development, education, research, operations, community service, purchasing, transportation, design, new construction, renovation and retrofit (Van Weenen, 2000).

Ecological landscape design is discussed under different parameters on the scale of "building, campus and city". It examines the relationship between building and open space in building scale, building energy usage, accessibility and green space system in urban scale, correct plant selection in campus scale, hydrological system, active transportation system, metabolic system, biodiversity, gathering and recreation areas, pedestrian routes, bicycle lanes, vehicle lanes and parking lots.

For a campus to be successful in terms of ecological design, it should have a landscape master plan. Unfortunately, most universities in Turkey and Selcuk University do not have a landscape master plan. A campus master plan is a comprehensive plan for the development of a campus. It defines not only potential sites for future development but also major landscape principles of the campus design. A sustainable campus landscape should have some regulatios to minimize the use of water, fertilizers, pesticides, labor and building materials.

Many universities in Canada, United States, United Kingdom have started the green design process in their campus. Carnegie Mellon, Cornell, Berkeley, British Columbia, Leeds Metropolitan University are siginificiant samples for their green design practices. Among these, Leeds Metropolitan University has a environmental policy which is regularly updated. It has full- time environmental management staff, the active support of senior management and published a biennial environmental report. The university's environmental management approach has provided a series of savings, despite an annual increase of $2.5 \%$ in student numbers. This approach has provided reduction in water consumption, through investment in supply infrastructure and conservation technology, limited their increase in gas consumption, reduced the consumption of paper and paper cost. The university also sets impressive targets, such as $5 \%$ reduction in $\mathrm{CO}_{2}$ emissions, $5 \%$ reduction in water consumption over two years and $25 \%$ reduction in waste going to landfill by 2006 (Simkins and Nolan, 2004).

An ecologically sustainable system that needs to be dealt with an economic and social sustainability tries to keep stable the natural resource base and it includes biodiversity, atmospheric balance and preservation of ecosystem functions (Harris, 2000). Some college campuses which were planned through this approach in Turkey are ITU (Istanbul Technical University), Piri Reis University and ODTU (Middle East Technical University). Among these, biodiversity and habitat restoration activities are carried out on the METU campus. Piri Reis University has been serving as an environmental friendly green campus since 2013 and it has an it is an internationally acreditated green campus.

A case study was done on the ecological design approach in campuses, under the topics of open space system, right plant and building material selection, hydrological system, active transportation system, recycling, energy and nature diversity, maintenance, materials. Evaluation in terms of energy saving, waste management, sustainable landscape materials, water management, protection of wildlife, landscape maintenance, transportation and parking were conducted.

In this study a "case study method" has been used. This method was developed by the Landscape Architecture Foundation (LAF) in 1997 and has become increasingly common in landscape architecture. The "landscape case study analysis" includes analyzing the design results of the project and conclusions.

In this study, Selçuk University Campus was analyzed under the topics of "energy conservation, waste management, materials for sustainable landscape, water management, wildlife habitat conservation, landscape maintenance, transportation and parking". The obtained results have been developed to provide guidance on campus ecological landscape design.

Location and transportation relations of Selcuk University : Selçuk University Alaaddin Keykubat Campus is located in Selçuklu district and is located at 38.020092 latitude and 32.514507 longitude (Fig. 1). It is located on the Afyon road, 
approximately $20 \mathrm{~km}$ from the city center. The campus can be reached from the city and the surrounding area by public transport such as tram and minibuses.

In addition to educational buildings, the campus has a large capacity medical school hospital, mosque, animal hospital, research and application areas related to Agriculture Faculty, greenhouses, nursery, shopping center and other commercial buildings, banks, sports fields, cultural center, student dormitories and central library (Fig. 2).

Climate : The central and northern parts of Konya City are under the influence of terrestrial climate, where winters are rainy and cold and summers are hot and dry. The average rainfall in Konya is below $500 \mathrm{~mm}$. Central Anatolia, the region with the lowest precipitation, was naturally the most affected area in drought. In this region, rainfall is usually effective in winter and spring. In the region, where the city is located, north-onset winds prevail and the ones north-west (Karayel) and northeast (Poyraz) directions are most active. Water potential in Konya sub-basin is higher than other sub-basins (990 $\mathrm{hm}^{3}$ per year) (Anonymus, 2015).

Soil : Due to climate, topography and main material differences, various major soil groups were formed in Konya. Alluvial and

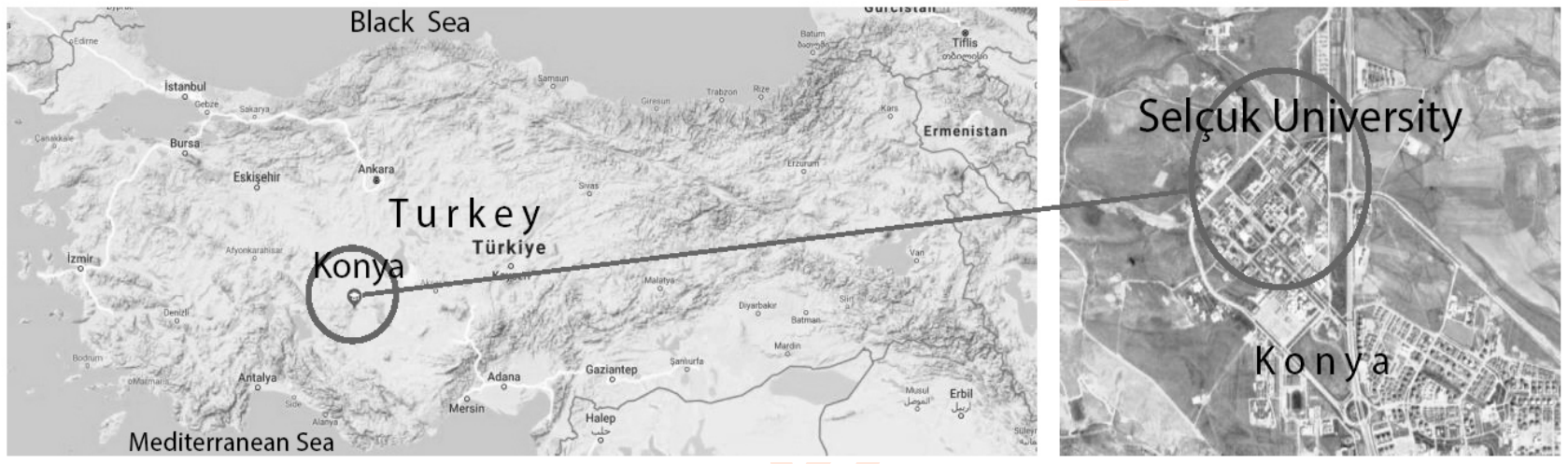

Fig. 1 : Location of Selcuk University Campus in Turkey and Konya.

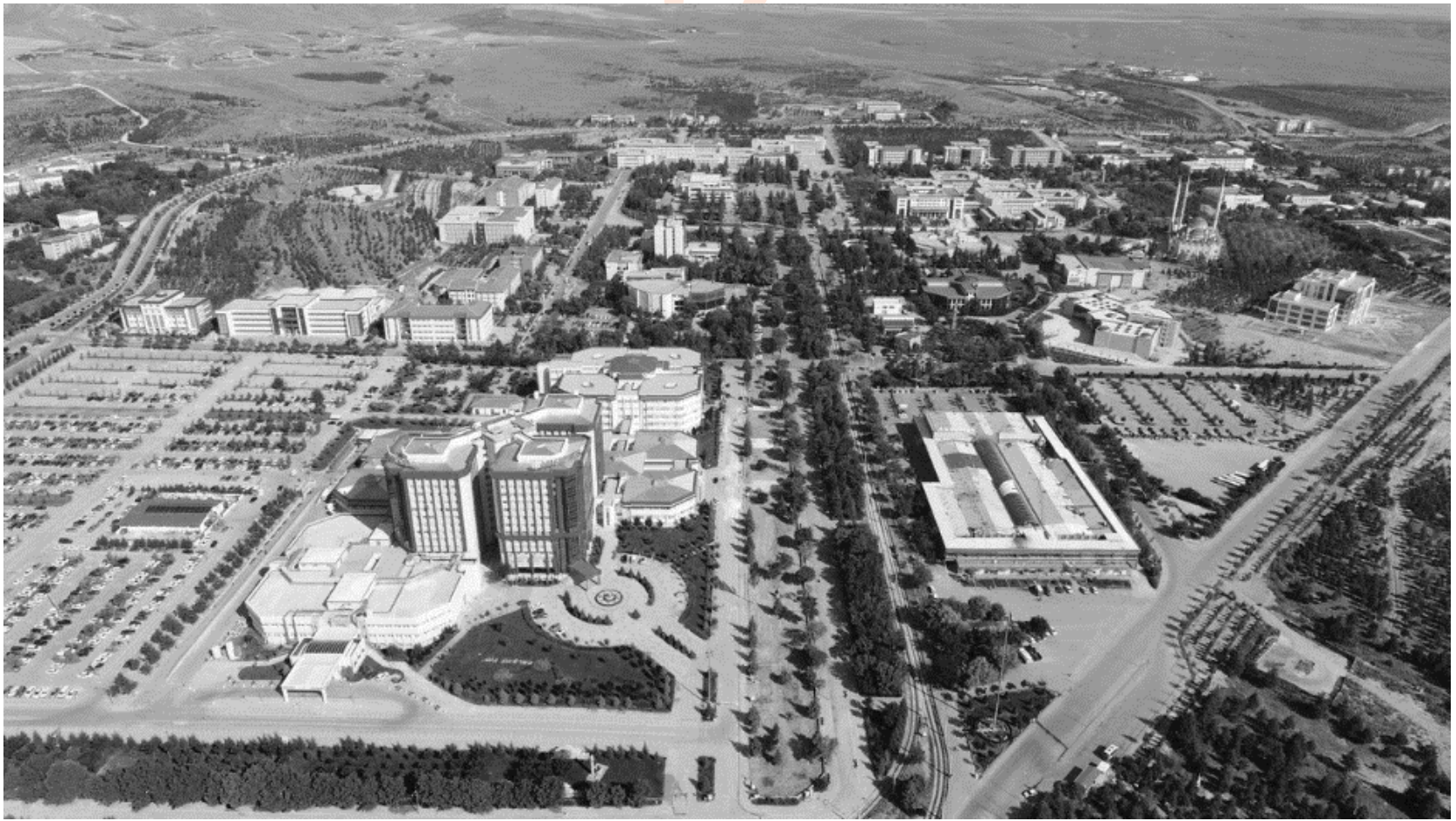

Fig. 2 : General view of Selcuk University. 
colluvial soils dominate the city and its immediate surroundings (Önder and Aklanoğlu, 2006). The area where the campus is located within the scope of "land use capability classes" is in the scope of class IV (Akseki and Meşhur, 2013).

Topography : Konya City and Selcuk University Campus is located on a flat area and this area is composed of alluviums carried by floods and winds from the surrounding hills for centuries (Akseki and Meşhur, 2013).

Evaluating selcuk university campus in terms of ecolgical landscape design : As it is indicated in the method part of this study, Selcuk University Campus will be analyzed under the topics of "energy conservation, waste management, materials for sustainable landscape, water management, wildlife habitat conservation, landscape maintenance, transportation and parking".

"Energy conservation" is one of the important issues on ecological design. Through a rational use and management of natural elements or processes, energy can be conserved. However, some of the negative effects of sun and wind can be minimised. Energy conservation by landscaping will regulate energy flows coming from sun and wind.

In this part of the study, the use of topography and land use, building orientation, vegetation, green roofs, water, energyefficient landscape lightening and renewable energy types on campus will be discussed.

The "topography" on campus does not offer different opportunities in terms of sunlight, wind control and exposition, because the campus is on a flat area.

"Building orientation" designed through green design approach maximizes opportunities for passive solar heating. Selcuk University Campus is located on a flat area, so the area doesn't offer topographical variability. This situation doesn't give an opportunity to control the sun light and wind through exposition. Almost all the buildings in the campus area located nortwest-southeast direction. This direction gives optimum daylighting throughout the year and passive solar heating opportunities to the users of the building under terrestrial climate conditions. However, the buildings in the campus area are far from each other and they located the way they won't block their sunlight. By this way energy use for lighting buildings can be minimised by letting the natural light in by orientation and the internal layout of the building.

In terms of "vegetation" a common project is being carried out with the Regional Directorate of Forestry in order to make the campus environment more green. Within the scope of the project, afforestation or soil conservation application project will be prepared for the areas suitable for afforestation by conducting soil analyzes of the site. The objective of the project is to plant 153 thousand samplings of 12 different species in an area of $₫ 1$ million 800 thousand square meters. With its current status, Selcuk University ranks $349^{\text {th }}$ in the Green Metric Ranking worldwide (Url 7). Selcuk University is amongst the 9 Turkish universities which are in green metric (Güngör and Demir, 2018).

This project will make significant contributions to reduce the heat island effect in the campus area which is under the influence of terrestrial climate. However, the current plantation of the Selcuk University Campus is not the product of a plant design project. Therefore, there is no design that minimizes the negative effects of wind and sun on buildings.

"Green roofs" or vegetated roof covers are the structural elements that minimize the energy loss by insulating the buildings in winter. They also reduce air conditioning need in summer. In Selcuk University Campus there isn't a green roof application. However, there are some vertical planting samples that are reducing the solar radiation (Fig. 3 ).

"Water" has a significiant impact on climate control. It provides some cotributions especially in the utilization of solar radiation and energy conservation. Location of water bodies can also affect the thermal conditions at the site, especially in built environments andthey can affect the microclimate of the site. In such a large area like Selcuk University Campus area, there isn't a water body. Consequently, in hot summer days, users of the area lack cooling effect of a water surface.

In the campus there isn't an "energy efficient lighting technology", however, there is a solar power plant and university meets one third of its annual need with 5.5 million kilowatt hours of electricity obtained from this power plant, which is set up on an area of 20 thousand $\mathrm{m}^{2}$. This structure will provide free electricity to the university for 20 years. In addition, positive results were obtained from the researches carried out (Köse, 2011) to establish windmills in the campus area and necessary studies were started for this purpose.

On the "waste management" issue, waste reduction and recycling, composting, on-site wastewater treatment system can be searched (Tuna, 2006). "Waste reduction and recycling" activities are the most popular campus greening programs. Most of the American Universities support "sustainable campus image" in their campuses by having waste management and recycling programs

"Materials for sustainable landscape" supports a sustainable campus landscape and its aim is to use materials that 


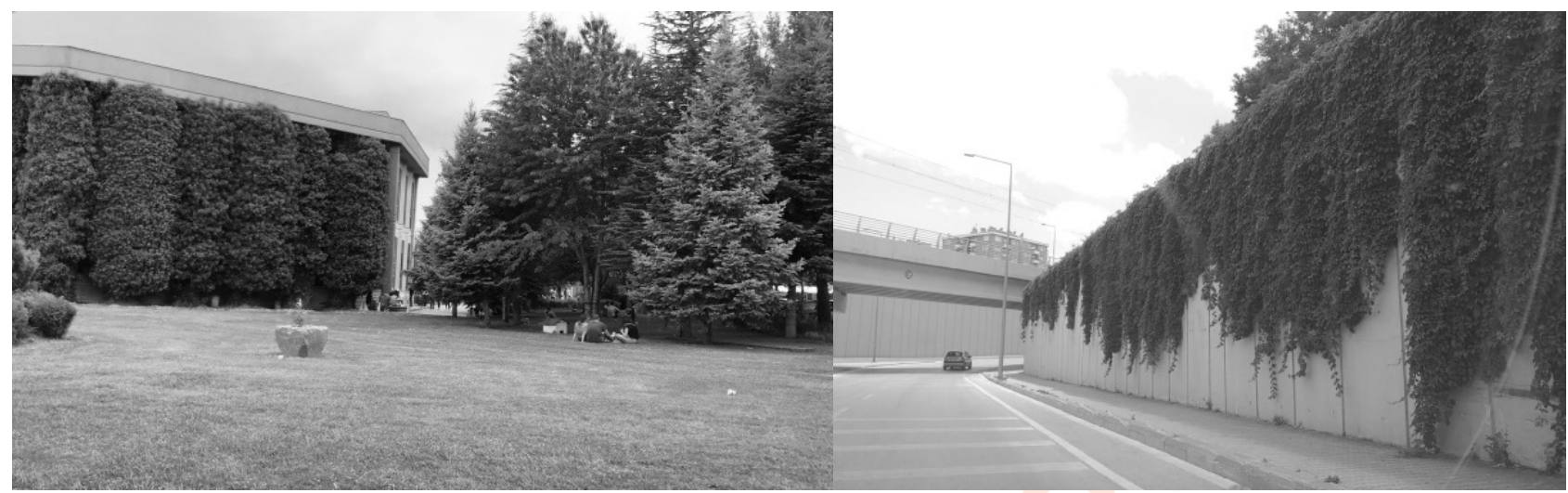

Fig. 3 : Vertical planting walls on campus (Original, 2019).

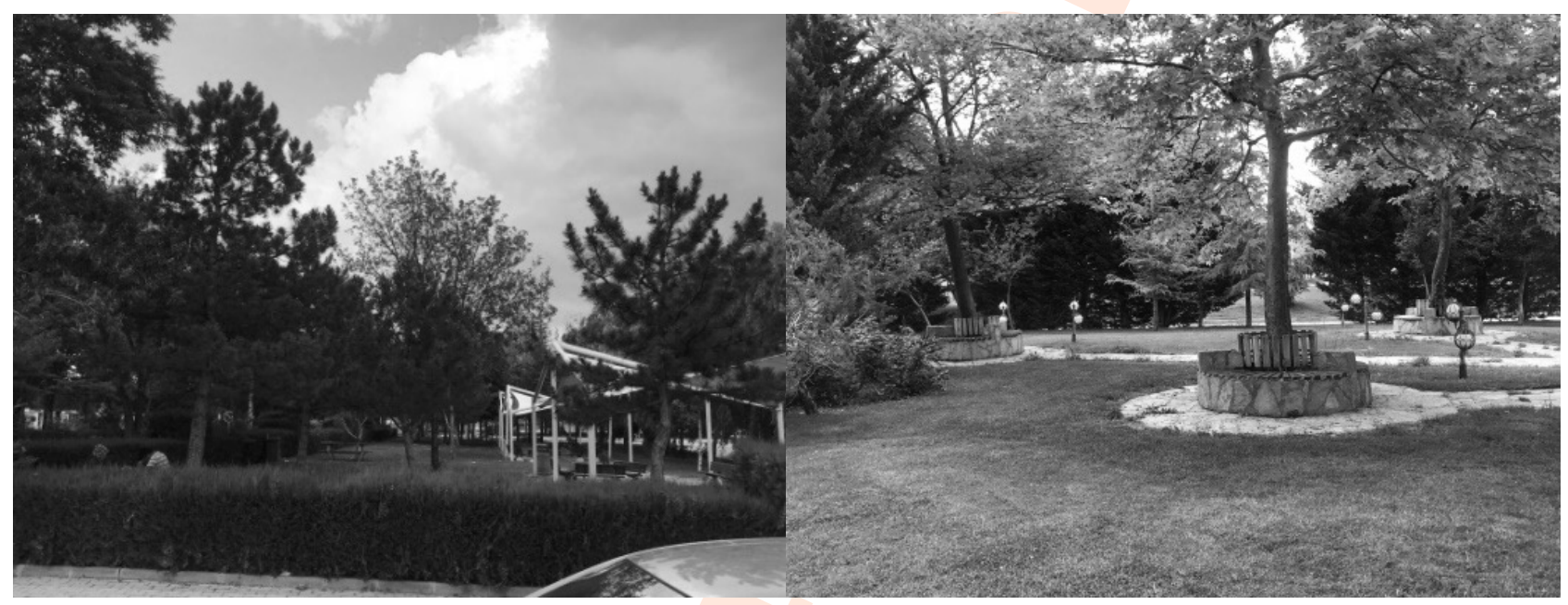

Fig. 4 : Deciduous and evergreen trees on campus (Original, 2019).

may have minimum impact on the environment and maximize outputs of resources that are reusable.

If it is taken a look at "soft landscape-plant material", it should be said that the preferred plant species on campus are compatible with the ecological conditions and physical structure of the region. On the campus, trees, shrubs, ground covers, perfoliates and grass types are used which are compatible with the terrestrial climate of the city and require little or moderate water.

It is an ecologically correct approach to use evergreen and deciduous tree species in green areas within the campus, especially in central areas and active green areas. This allows active use under high crown and relatively fast-growing leafy trees. This balance in species selection helps to create a favorable microclimate on campus in summer (Fig. 4). Coniferous trees were used for afforestation in open spaces surrounding the campus. Coppice forests containing pine (Pinus nigra) and cedar (Cedrus libani) trees are some of the tree species used in these areas. Some of the other trees that have been used on campus are white birch (Acer negundo), horse chestnut (Aesculus hipocastanum), linden (Tilia tomentosa), sycamore (Platanus orientalis) etc. (Polat et al., 2018)

In the road afforestation within the campus, deciduous trees with shade are generally used. This is advantage our for pedestrians using pavement (Fig. 10). In some of the road afforestation, shade trees were not used and trees were selected just with aesthetic concern (Fig.11).

For effective use of water, especially on the large areas ground covers should be used instead of grass. Because grasses are the most consumed plant surfaces. Evergreen grass species require regular watering and maintenance in summer and winter, so their water consumption is high. Grass species, such as "Cynodon dactylon" spend the winter asleep (rest period outside vegetation) and do not require much water during sleep periods. This makes maintenance easier. In areas that are not suitable for 


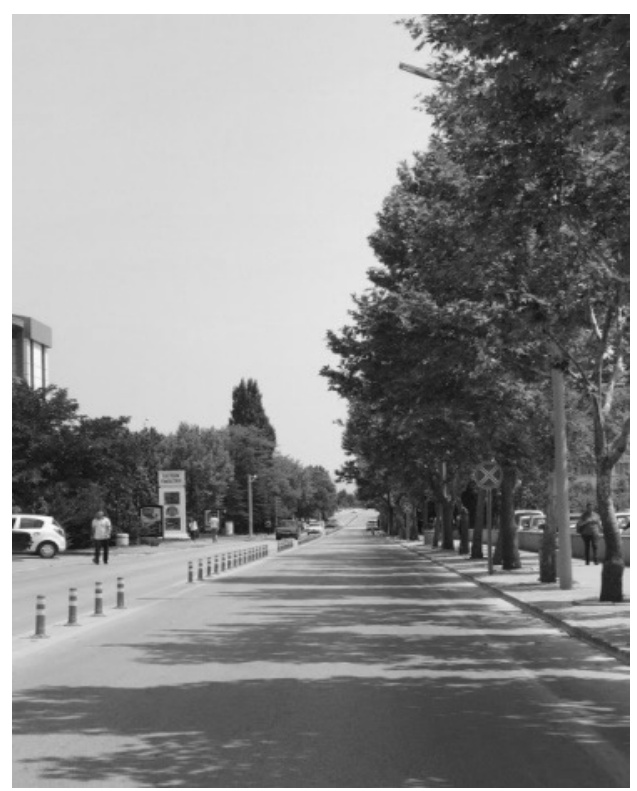

Fig. 5 : Street trees on campus (Original, 2019).

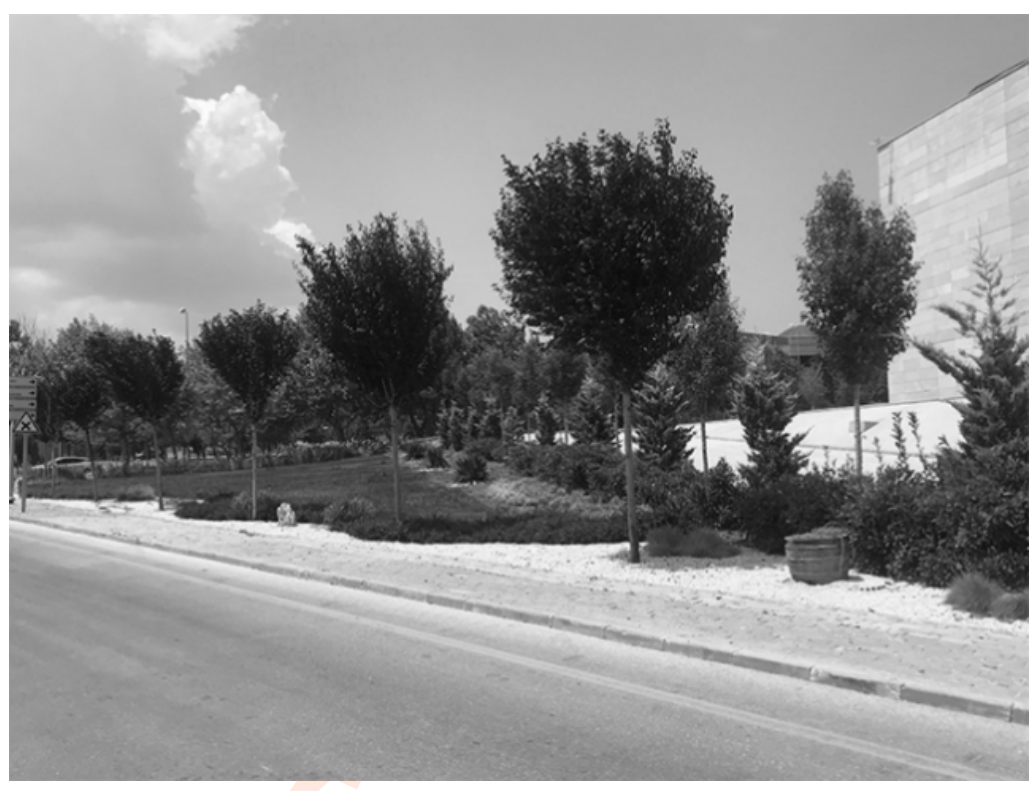

Fig. 6 : Street trees on campus (Original, 2019).

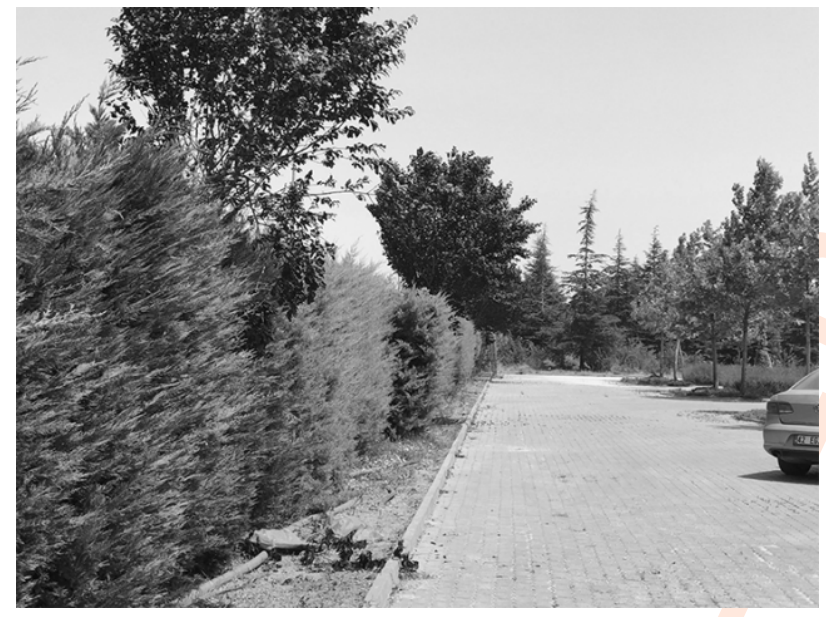

Fig. 7 : Living walls surrounding parking lot in campus (Original, 2019).

growing grass or where lawn maintenance is too costly and difficult, cover / meadow plants (alfalfa, twitch, etc.) can also be used as mixtures (Keane, 1995). When the "selection of appropriate types of plants" searched in Selcuk University Campus, it can be observed that on campus; grass plants are preferred instead of groundcover plants. In addition, the grass seed mixture was used in species with low water demand in terms of drought landscaping (Festuca arundinacea, Festuca ovina). It also stated that irrigation of this species is limited and it would be right to use it in problematic and low maintenance areas (Tülek and Barış, 2011; Bayramoğlu and Demirel, 2015; Demiroğlu et. al., 2016).
In the campus, the fact that coniferous trees are generally used in large afforestation areas in passive green areas around the campus is a positive approach in terms of water economy, because the plants like Pinus nigra and other coniferous trees have low water demand.

The use of native plant species also reduce the water consumption and mentenance costs. In the campus area, together with being some of them wild, native plants are used. They are selected on campus because they are adapted to the extremes of drought and heat that are common in Konya. Creating living fences and walls is another way to support sustainable landscape (Fig. 7).

On choosing "hard landscape materials", the impacts of material on the environment should be considered. On this issue, maintenance requirements, reusing and recycling opportunities of the material, cost, fitness for purpose are important (Tuna 2005). Materials used on campus equipment have no harmful effects on the environment. Generally, wood, concrete and metal materials are used in the reinforcement. The cost and maintenance cost of these materials are not high. The materials are suitable for their intended use. However, there are no other furnitures built on the campus using recycled materials. Vario us practices for water conservation such as "xeriscaping, native planting, shading, mulching, maintenance, soil improvement, site design with permeable materials" are related to "water management" (Tuna, 2006).

The fact that the plants selected on campus are low and medium water needs are compatible with the climate that 

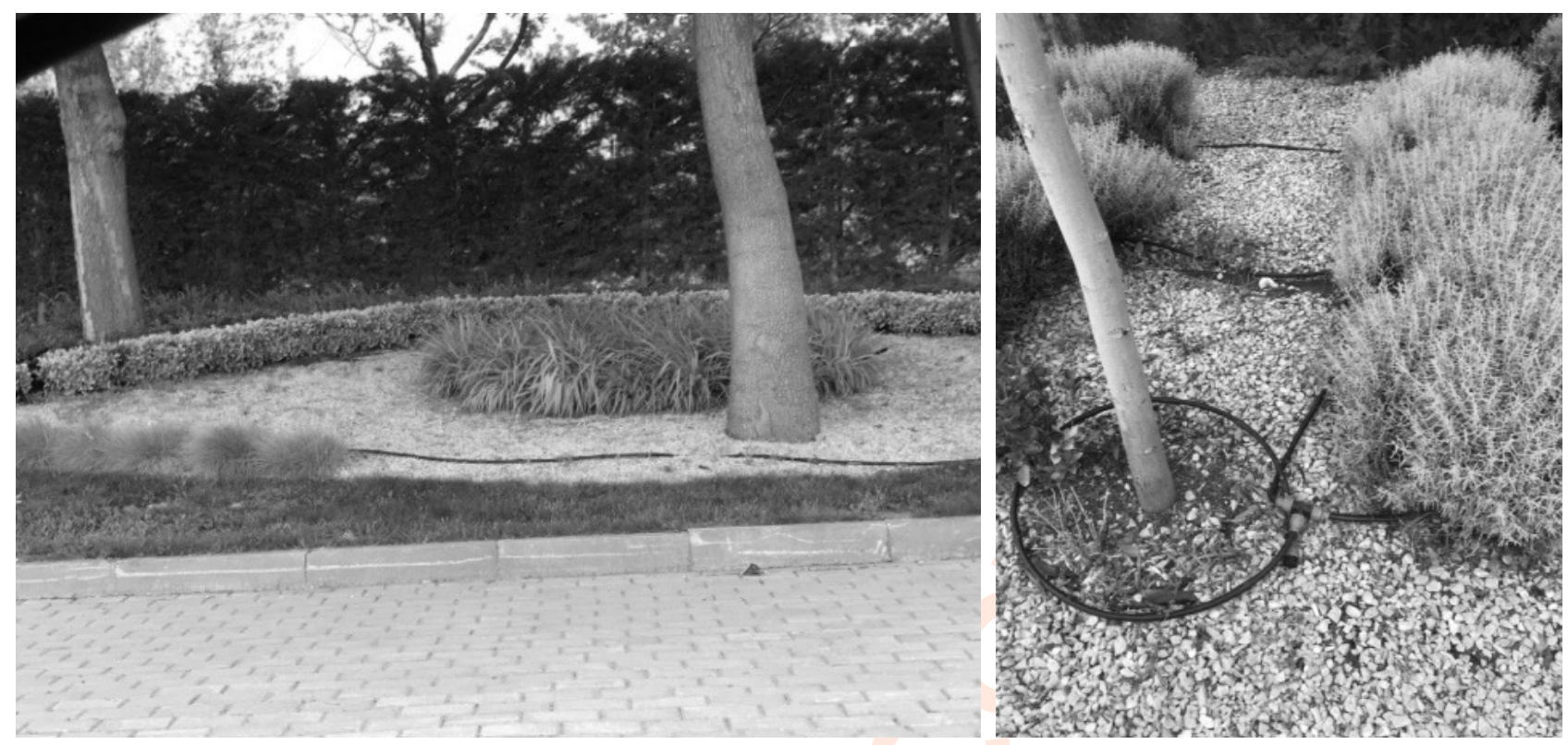

Fig. 8 : Mulching and drip irrigation samples on campus (Original, 2019).

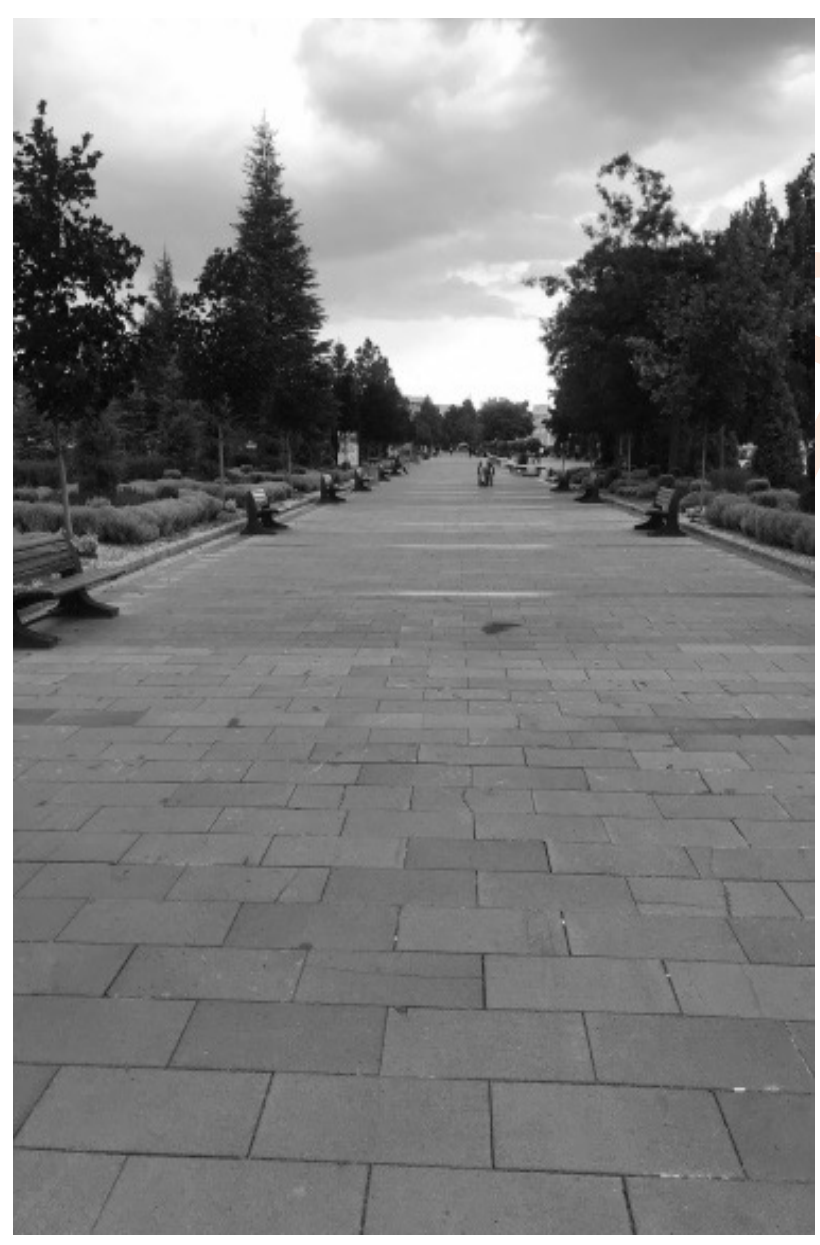

Fig. 9 : Pedestrian path on campus (Original, 2019). characterizes the area and can be described as xerophyt. The presence of many deciduous trees on campus provides shade throughout the campus. Mulching on campus is not very common and is applied only in small areas. In these areas, gravel is used which causes more heat radiation than other natural mulch materials (Fig. 8). Drip irrigation system on campus is easy to maintain and periodically controlled and maintained. According to the statements of "Selcuk University Afforestation and Landscape Unit" soil improvement techniques used in the planted areas on campus (Fig. 8). Almost all planted areas in Selcuk University Campus are irrigated by "drip irrigation" method. Drip irrigation especially in large afforestation areas surrounding the campus saves water to a great extent. Grass areas are irrigated by automatic irrigation system.

On campus, there are no "rainwater harvesting system", which may be implemented through downspouts, rainwater diversion, catchments and storage tanks. "Drainage" on campus, there is a conventional drainage system rather than a sustainable drainage system. In Selcuk University Campus, it is observed that the hard landscape solutions that can serve the protection of water and water cycle in nature are not sufficient. For example, while making the land use decisions for the campus area, it was seen that the hydrological structure of the area was not considered correctly, the surface flow was mostly interrupted by impermeable surfaces, and drainage nets and drainage points generally coincided with hard floors and buildings. There are no hard permeable floor coverings on campus that canalize rain water directly into the soil. Also on campus, there are no applications for rain harvesting such as rain gardens. 


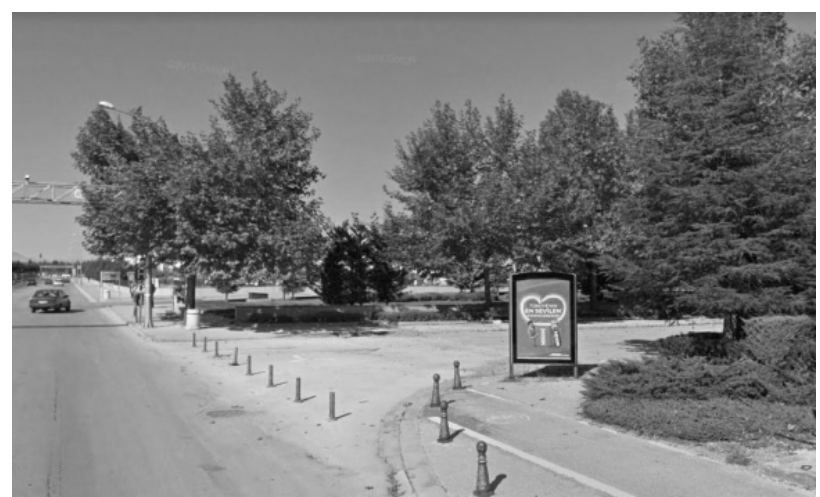

Fig. 10 : Interrupted bcycle route on campus (Original, 2019).

Since the landscape of the campus is not natural, natural green areas and corridors and wet areas that support wildlife cannot be mentioned. Consequently, planning and design studies that support wildlife habitat conservation cannot be mentioned within the campus.

In the campus for "landscape maintenance" practices; vegetation removal, mowing, trimming, weeding, irrigation, using fertilizers and compost (bark), prunning, maintaining hard landscape, equipment maintenance are done.

"Transportation and parking" is another significant issue for ecological landscape planning in campuses. "The heaviest vehicle volume is usually seen by parking areas, building entrances, pedestrian drop-off and pick up points. Promoting and encouraging public transportation other than single-occupancy vehicle is the key to greening campuses with respect to land-use and transportation planning" (Tuna, 2006). In Selcuk University Campus, public transportation services such as shuttle busses and tram are intensively used by the students. Most of the students accommodate close to the center and they usually use public transportation. However, there the shuttle busses allocated for the professors are not enough (two times a day), so they are generally come to campus by their car. Although public transportation is used so intensively, the vehicle density is so high in the education terms. In the campus, some vehicle sharings such as ridesharing, carpooling and vanpooling are not common. There isn't any road infrastructure neither in the city nor on campus.

The pedestrian and bicycle paths on the campus are connected to the adjacent streets and routes, but secure crossings are not provided at the intersection of the bicycle paths with the vehicle paths.

On-campus parking is free. Besides, vehicles in the city and campus do not use renewable fuels. According to the $\mathrm{PM}_{2,5}$ measurement results in Selçuk University campus open areas, particulate matter concentration was high, especially in winter and during peak hours (Dursun et al., 2017).

There is no underground car park within the campus. There are two large car parks, one for hospital and other for shopping center. "Platanus orientalis"and "Cupressosy parisleylandii" have been used in the planting of parking lots where hard ground covers a large area. The use of Platanus orientalis, a long-lived shade tree in parking lots is a right decision in terms of reducing solar radiation and reducing heat island effect.

Some materials such as asphalt and some other imperveous materials used for paving can cause heat rising over a parking lot on hot days. For the solution, reducing the amount of paved and impervious surface area can prevent air pollution and heat. In the campus, concrete material is used in autoparks, as it is durable and drains a certain part of rain water.

Bioswales and rain gardens are some of the design features that may be installed in parking lots. By this way, water runoff can be controlled and treated. There are not such practices in parking lots on campus. Another important issues on ecological landscape planning on campuses are bicycle and pedestrian routes. An ideal campus transportation should be arranged placing the primary concern on pedestrians (Kalın et al., 2019). In Selcuk University Campus, pedestrian spaces are insufficient and walking distances to the tram stops are too long. There is only 100 meters of pedestrian path on the campus (Fig. 9). The pedestrian circulation, which should be designed uninterruptedly on campus, should be expanded from place to place by means of meeting areas allocated for various activities (Polat et al., 2018).

Since, the campus does not have a master plan, the pedestrian path is a road that is subsequently converted from the vehicle path and is a non-binding road between functions. The pedestrian path does not meet the requirements within the campus area, which is quite large. Generally in the campus area students walk on sidewalks. Especially, the pedestrian places, should be connected to the tram stops, because a number of students have to use some busy motorized routes just after getting out of tram.

"Bicycle routes provide alternative transportation, reduce traffic, save parking spaces and make biking safer". They also provide recreation opportunities (Tuna, 2006). There is no particular planning for the bicycle path to Selcuk University campus. For this reason, the continuity of cycling paths within the campus was not provided (Fig. 10). "On campus, motor vehicle, pedestrian and bicycle tracks must be designed in an integrated manner" (Polat et al., 2018). 


\section{Results and Discussion}

Designing university campuses which are an important component of urban ecosystems, on the direction of ecological planning principles, will contribute to the sustainability of both the campus and the city and even the region in which it is located. Ecological sustainability, which should be dealt along with economic and social sustainability approaches, will emerge with an accurate landscape design approach. First of all, this planning approach requires determination of ecological conditions of the campus area and its surrounding environment, and also determining the and use potential. However, the campus project should be achieved through a teamwork led by planner-designer disciplines, which form the ecological infrastructure (Yilmaz et al, 2005).

Selcuk University is one of Turkey's largest universities in terms of student capacity. Although some good approaches and practices have been observed in terms of ecological landscape design on campus in terms of evaluation criteria, some deficiencies and issues that need to be developed have been identified. Below are the recommendations made for the evaluation criteria used in this study for the campus of Selcuk University:

Energy conservation: On campus, windbreaks or shelterbelts should be constructed to control wind. Constructing green roofs and creating an energy efficient landscape are some other solutions for energy conservation.

Waste management: On campus, compost use of compost should be increased and compost materials should be diversified. It may be investigated to construct an on site composting plant. Outdoor recycling containers should be increased at appropriate places in the campus area.

Sustainable landscape materials: Recycled materials should be used when needed on campus. Some structures should be built to collect rainwater and stormwater.

Water management: In the campus, opportunities to create a lake that can collect rainwater runoff, and landscape should be redesigned with less water requirement such as using rainwater, constructing rain garden. In addition, rather than materials such as asphalt, concrete etc., that does not allow rain water to get through, permeable structures and materials should be used. By increasing permeable surfaces on campus that canalize rain water directly into the soil will reduce surface runoff. However, these practices help to restore the ground water lost in dry seasons (Ermeydan and Yüksek, 2017).

Wildlife / Habitat conservation: Some plant species should be used to attract butterflies and other wildlife. On campus, creating a lake can be support wildlife on campus. In addition to these, someplants which can attract butterflies may be used on campus and some animal shelters can be built and settled on some places (Gungör and Demir, 2018).

Pest management: On campus, pesticide is applied to campus landscape depends on inspection (Anonymus, 2019). Decreasing pesticide use, instead using cultural and biological controls may be more ecological landscape management approach.

Landscape maintenance: The soil should be improved soil by mulching with organic materials such as barks and pine needles and compost using should be increased. Reducing the area of grass surfaces and increasing mulching surfaces will save water (Polat etal., 2018).

Transportation and parking: In the campus, in spite of public transportation is used extremely, private car using level is high as well. For the solution, car entrance on the campus can be limited and parking fee implementation should be started. Safe and comfortable pathways can be designed for pedestrians and bicycle users. In addition to this, interrupted bicycle routes should be planned and some planning approaches should be developed to make them continuous.

Based on the numerical data obtained, since private vehicles within the campus area are an important source of pollution; in this regard, students, academicians and employees should be encouraged to public transport, traffic flow routes should be revised, regulations on the construction of safe bicycle/ pedestrian roads on campus should be made and green area works should be increased. In addition, it was determined that the pollution caused by fossil fuels increased especially during the winter months on campus. As a measure to reduce fossil fuel consumption, in addition to the use of systems such as electrical heaters and solar heaters on a building scale, natural gas, which generates less emission, can be the solution.

On campus, underground garages may be a good solution for increasing air quality, heat island effect and other microclimatic effects by reducing hard surfaces and increasing green areas. Some solutions should be investigated to build underground garages on campus. On campus, some opportunities should be investigated to create bioswales infiltrating road and parking-lot runoff in. Opportunities for inter campus shuttle buses powered by electricity or other alternative renewable energy sources should be investigated.

Achieving campus sustain ability and sustainable landscape design more effectively is not possible without the 
cooperation and involvement of all stakeholders such as students, faculty and staff, university management, funding agencies, and community (Jones, 2008). In order to sustain an ecological landscape planning and design, an environmental stewardship in cooperation with municipalities, nongovernmental organizations, university organizations including students and academicians are required. In addition to this, educational improvements in curriculum, organising some forums and campaigns; arranging student projects, audits and internships using media to promote sustainable design can be useful. Improving campus landscape for educational use by labeling plants, creating outdoor classrooms, creating demonstration and theme gardens, creating arboretum will support the ecological sustainibility of campus landscape.

\section{References}

Akseki, H. and M.Ç. Meşhur: Kentsel yayılma sonucu yapılaşmaya açılan verimli tarım alanları: Konya kenti deneyimleri (An analysis of the Konya's urbanized fertile agricultural land sand urban sprawl). Megaron, 8, 165-174 (2013).

Alshuwaikhat H. M. and I. Abubakar:An integrated approach to achieving campus sustainability: Assessment of the current campus environmental management practices. J. Clea. Produc., 16, 17771785 (2008).

Anonymus: Konya Havzası Kuraklık Yönetim Planı. Türkiye Cumhuriyeti Orman ve Su İşleri Bakanlığı Su Yönetimi Genel MüdürlüğüTaşkın ve Kuraklık Yönetimi Dairesi Başkanlığı. Dolsar Mühendislik, Konya BasinDrought Management Plan. Ministry of Water Management of the Republic of Turkey General Directorate of Water Affairs and Forestry Flood and Drought Management Department. Dolsar Engineering (2015).

Bayramoğlu, E. and Ö. Demirel: Xerophytic Landscape: Environment and ecology at the beginning of $21^{\text {st }}$ century (Eds.: R. Efe, I. Cureba, C. Bizzarri and G. Nyussupova). St. Kliment Ohridski University Press, Sofia (2015).

Birkeland, J.: Design for Sustainability: A sourcebook of integrated, ecological solutions. Earthscan Publications. London (2002).

Bogunovich, D.: Eco-TechUrbanism: Merging Urban Design with Clean Technology. Presented at the First International Conference in Eco-Tech Cities at the Gazi University, Ankara (2008).

Demiroğlu, D., A.A. Karadağ, A.E. Cengiz and A.S. Günaydın: Evaluation of sustainable water using at open and green spaces: Kilis 7 Aralık University Main Campus. Evaluation of sustainable water using at open and green spaces: Kilis 7 Aralık University Main Campus. International Conference on Natural Science and Engineering (ICNASE'16), pp. 3171-3183 (2016).

Deniz , B., E.V. Küçükerbaş and H.E. Tunçay: Peyzaj ekolojisine genel bakış. ADÜ ziraat fakültesi dergisi. Overview of landscape ecology. ADU J. Fac. Agric., 3, 5-18 (2006).

Dursun, Ş., Z. Ayturan, C., Kunt, F., Ulusoy, Ç., Ö. Çimen Mesutoğlu: Selçuk Üniversitesi Yerleşkesi Açık Alanlarda Ortam $\mathrm{Pm}_{2,5}$ Seviyesinin Belirlenmesi. VII. Ulusal Hava Kirliliği ve Kontrolü Sempozyumu Bildiriler Kitabı. Hava Kirlenmesi Araştırmaları ve Denetimi Türk Milli Komitesi. Akdeniz Üniversitesi Mühendislik Fakültesi Çevre Mühendisliği Bölümü 1-3 Kasım. Antalya. Determination of Ambient Pm2,5 Level in Open Areas of
SelcukUniversityCampus. VII. National Air Pollution and Control Symposium ProceedingsBook. Air Pollution Research and Control Turkish National Committee. Akdeniz University Faculty of Engineering Environmental Engineering Department, Antalya (2017).

Ermeydan M. and R. Yüksek: Taşkın cadde peyzajlarında yağmur suyu yönetimi üzerine görüşler. Plant Peyzaj ve Süs Bitkiciliği Dergisi. (Opinions on rain water management in flooded street land scapes). J. Plant Landsc. Orname. Crops, 7, 90-95 (2017).

Forman, R.T.T.: Land Mosaics : The ecology of landscapes and regions. Cambridge University Press, Cambridge (2001).

Güngör, S. and M. Demir: Studying of sustainable design process in university campuses and suggestion for sustainable campus design in Selcuk University. II. International Eurasian Agriculture and Natural Sciences Congress. Azerbaijan-Baku, pp. 204-210 (2018).

Harris, J.M.: "Basic Principles of Sustainable Development". Global Development and Environment Institute Working Paper 00-04. USA: Tufts University (2000).

Hersperger, A.: Landscape ecology and its potential application to planning. J. Plann. Liter., 94, 14-16 (1994).

Jones, P., C.J., Trier, J. P. Richards: Embedding education for sustainable development in highereducation: A case study examining common challenges and opportunities for undergraduate programmes. Inter. J. Educ. Res., 47, 341-350 (2008).

Kalın, A., M. Yurtcan and B.Ç. Kurdoglu: Example of a recreationorientedcycletrackdesign at university campuses. J. Environ. Protect. Ecol., 20, 965-975 (2019).

Karr, J.: What from ecology is relevant to design and panning. In: Ecology and Design: Frame works for Learning (Eds.: B.R. Johnson and K. Hill). Island Press. Washington D.C., pp. 133-172 (2002).

Keane, T.: Water wise landscaping guide for water management planning, 103. Utah State University (1995).

Kıııç, S.: Çevreci sosyal hareketlerin ortaya çıkışı, gelişimi ve sona ermesi üzerine bir inceleme. Ankara Üniversitesi SBF Dergisi. A study on the emergence, development and termination of environmental social movements. Ank. Univer. J. Soci. Sci., 57, 93-108, Ankara (2002).

Köse, F.: Konya Bölgesi Rüzgar Enerjisi Potansiyeli ve Bunun Kullanılmasında Lisanslı ve Lisanssız Üretimlerin Değerlendirilmesi. I. Konya Kent Sempozyumu Bildiriler Kitabı. Konya II Koordinasyon Kurulu. 26-27 Kasım. (Evaluation of Licensed and Unlicensed Generation in the Wind Energy Potential of Konya Region and Its Utilization. I. Konya City Symposium Proceedings Book. Konya Provincial Coordination Committee.) pp. 471-486. Konya (2011).

Nassauer, J.I., Z. Wang and E. Dayrell: What will the neighbors think? Cultural norms and ecological design. Landscape and Urban Planning, 92, 282-292 (2009).

Önder, S. and F. Aklanoğlu: Konya kenti peyzaj gelişim stratejileri. Selçuk Tarım Bilimleri Dergisi. Landscape development strategies of Konya City. J. Agricult. Sci., 20, 23-26 (2006).

Özsoy, T.: Tüketim ve Çevre llişkisi. Disiplinlerarası BakışAçısıyla Çevre. Editedby Günaydın ve Özsoy. Hiperlink Yayınları:73. Relationship between Consumption and Environment. Environment from an Interdisciplinary Perspective. Hyperlink Publications: 73. İstanbul (2014).

Simkins, G. and A. Nolan: Environmental Management Systems in 
Universities. Occasional Paper for the Environmental Association for Universities and Colleges (2004).

Polat, A.T., S. Güngör and M. Demir: Landscape design principles of university campuses: A case study in campus of Alaeddin Keykubat, Selcuk University. International Conference on Engineering and Natural Science- ICENS. 599-607. Sarajevo.

Todd, J., Brown, J.G. Erica and E. Wells: Ecological design applied. Ecol. Eng., 20, 421-440 (2003).

Tülek, B. and M.E. Barış: Orta Anadolu iklim koşullarında su etkin peyzaj düzenlemelerinin değerlendirilmesi. MKU ziraat fakültesi dergisi, evaluation of water efficient landscape arrangements in central anatolian climate conditions. J. MKU Facu. Agric., 16, 1-13 (2011).

Van Weenen, H.:Towards a vision of a sustainable university. Int. J. Sustai. HigherEduc., 1, 20-34 (2000).

Yeang, K.: Ecodesign: A Manual for Ecological Design. John Wiley \& Sons Ltd. UK (2006).

Yılmaz, O., K. Ak and A. Benliay: Yerleşke Tasarımının Ekolojik Boyutu. II. Ulusal Üniversite Yerleşke Planlanması ve Çevre Düzenlemesi Çalıştayı Bildiriler Kitabı, s 1-14. (Ecological Dimension of Campus Design. II. National University Campus Planning and Landscaping). Workshop Proceedings Book, 1-14 (2005). 